\title{
Factors hindering the implementation of the procurement plan in a selected national research utility
}

\begin{tabular}{|c|c|}
\hline \multicolumn{2}{|c|}{ 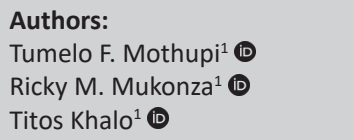 } \\
\hline \multicolumn{2}{|c|}{$\begin{array}{l}\text { Affiliations: } \\
{ }^{1} \text { Department of Public } \\
\text { Affairs, Faculty of Humanities, } \\
\text { Tshwane University of } \\
\text { Technology, Pretoria, } \\
\text { South Africa }\end{array}$} \\
\hline \multicolumn{2}{|c|}{$\begin{array}{l}\text { Corresponding author: } \\
\text { Tumelo Mothupi, } \\
\text { tumelofaith072@gmail.com }\end{array}$} \\
\hline \multicolumn{2}{|c|}{$\begin{array}{l}\text { Dates: } \\
\text { Received: } 23 \text { July } 2021 \\
\text { Accepted: } 28 \text { Sept. } 2021 \\
\text { Published: } 25 \text { Jan. } 2022\end{array}$} \\
\hline \multicolumn{2}{|c|}{$\begin{array}{l}\text { How to cite this article: } \\
\text { Mothupi, T.F., Mukonza, R.M. } \\
\& \text { Khalo, T., 2022, 'Factors } \\
\text { hindering the } \\
\text { implementation of the } \\
\text { procurement plan in a } \\
\text { selected national research } \\
\text { utility', Journal of Transport } \\
\text { and Supply Chain } \\
\text { Management } 16(0) \text {, a644. } \\
\text { https://doi.org/10.4102/ } \\
\text { jtscm.v16i0.644 }\end{array}$} \\
\hline \multicolumn{2}{|c|}{$\begin{array}{l}\text { Copyright: } \\
\text { (C) 2022. The Authors. } \\
\text { Licensee: AOSIS. This wc } \\
\text { is licensed under the } \\
\text { Creative Commons } \\
\text { Attribution License. }\end{array}$} \\
\hline \multicolumn{2}{|l|}{ Read online: } \\
\hline 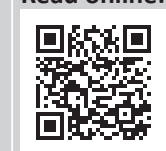 & $\begin{array}{l}\text { Scan this QR } \\
\text { code with your } \\
\text { smart phone or } \\
\text { mobile device } \\
\text { to read online. }\end{array}$ \\
\hline
\end{tabular}

Background: The management and funding of research in South Africa are managed at the national level by a dedicated public utility. However, the procurement plan implementation at the utility has been unsatisfactory and is hindered by various factors. The institution requests funding, but by the end of the financial year, not all of the funds would have been used up. Funds not utilised by the end of the financial year are returned to the National Treasury, which reflects poor performance in the Supply chain management unit.

Objectives: This study examines the factors hindering the implementation of the procurement plan at the National Research Foundation. This is crucial because National Treasury SCM Instruction 2 of 2016 and 2017 stated that some government institutions sorely undermine and weaken the ethos of the Public Finance Management Act and ultimately waste scarce resources that are intended to improve service delivery.

Method: A qualitative approach with interviews being the major data collection technique was applied.

Results: The findings revealed that there is a lack of support from SCM managers and that SCM officials lack dedication to their work. In addition, the results also reveal a knowledge barrier between Scientists and SCM practitioners.

Conclusion: The study recommends that SCM managers arrange quarterly meetings with project managers to discuss the progress of projects on the procurement plan. The National Research Foundation (NRF) business heads should offer support to SCM officials in an effort to assist them to fulfil their responsibilities. The SCM officials should train Scientists on SCM regulations, which would break the knowledge barriers existing between them.

Keywords: procurement plan; factors; project managers; supply chain officials; implementation.

\section{Introduction}

Most governments in the world spend more money on the provision of goods and services which are procured from the private sector. Moeti (ed. 2014:20) mentions that although government exists to enhance social welfare and improve the lives of the citizens they operate under constrained and scarce resources (financial resources). He further states that the government needs to manage scarce resources and ensure that they are used efficiently and effectively for maximum benefit. Financial resources need to be allocated across the three spheres of government (national, provincial, and local) to meet their social and economic objectives. Mukonza (2015) argues that the national government has to lead by example, plan efficiently and reduce some of their unnecessary expenditure and free up some financial resources which can assist the local government.

This study focused on the National Research Foundation (NRF), a public agency that promotes and supports research through funding in all fields of natural and social sciences, humanities, and technology. The NRF receives funding from the government and they are expected to have a procurement plan in place and implement it. This is a requirement from the National Treasury SCM Instruction 2 of 2016 and 2017 procurement plans, submissions, and reporting. The instruction state clearly that the procurement plan is used to promote efficiency and transparency, to improve service delivery, and to meet business needs to ultimately facilitate the delivery of effective services to communities. Furthermore, it is used to eliminate waste and corruption in the use of public funds. 
The problem is that most financial years, the NRF finds itself either implementing the plan late or having some projects not being implemented at all, judging by the procurement plan report, 2019 and 2020 signed on 20 March 2020. The approved NRF procurement plan (2020:2) shows that out of 93 approved planned bids, only 47 were implemented and awarded and 46 were not. Four bids were advertised, 1 bid was at the drafting of specifications stage, 8 bids at the evaluation stage, 16 bids were deferred to the next financial year (2020 and 2021) and 17 bids were withdrawn from the procurement plan. As a result, these problems lead to failure in meeting the agreed objectives by the supply chain management (SCM) unit in the NRF Board and reflect poor performance to the NRF Board Procurement Committee. All funds that are not utilised by the end of the financial year are returned to the National Treasury and this disadvantages potential service providers who always look forward to getting into business with the institution. Service providers supply government institutions with goods or services and earn some profit which in turn contributes to the economy by creating employment.

The National Treasury guidelines issued on the implementation of demand management (2011a:3) states clearly that procurement planning should take place at the beginning of the financial year when the institution's strategic plan and budget have been approved. A procurement plan cannot be developed in isolation; it should form part of the institution's functional strategies. Public Affairs Research Institute (PARI) (2014:25) add that strategic planning documents identify activities to be performed and should be aligned with the procurement plan. However, according to PARI in South Africa, this is normally not the case as strategic planning documents are in most times of poor quality, and regularly not evidence-based. In turn, procurement planning is delinked from broader strategic plans.

This article examines those factors that hinder the progress of the NRF's procurement plan. To critically explore these factors, this study employed a qualitative method to collect data using unstructured interviews. The following section outlines the NRF background, unpacks public procurement, reflects on the findings from the empirical review, presents the findings and the analysis of the study, and lastly, the conclusion and recommendations.

\section{Literature review}

\section{Background of the National Research Foundation}

According to the National Research Foundation (n.d.), NRF is a government entity established through the NRF Act (Act No 23 of 1998). Through the Minister of Science and Innovation, the NRF requests funds from the government to be spent on public procurement for them to meet their objectives. As a government agency, the NRF has seven business units and they exist to support the development and implementation of national strategy and policy by promoting and supporting research through funding, human resource development, and the provision of National Research Facilities in all fields of natural and social sciences, humanities and technology. Together with universities, research institutes, business industry, and international partners, the NRF acts as a catalyst of knowledge production in science and technology to improve the quality of life of all the people of the Republic.

To achieve the NRF objectives and to make sure that resources are in place to conduct scientific research and space programmes, equipments and materials are needed and therefore procurement of goods and services need to occur. To do so, it is stated in the 2017 and 2018 NRF SCM Policy that business units are required to perform proper business planning, including procurement planning. This is a legal requirement in terms of the Public Finance Management Act 1999 section 53. It is also stated in National Treasury Instruction Note No 33 of 2011 and 2012 in conjunction with the National Treasury Regulations 2005, section 30 which stipulates that public entities should submit their strategic plans which include multiple-year projections of planned expenditure. To enable efficient expenditure or acquisition from third parties to deliver goods and services, the business units need to plan their procuring transactions and manage the execution thereof. This procurement planning is critical for the efficient utilisation of revenue and income that the minister provides for in the budget of the NRF. However, some factors hinder the progress of the procurement plan in the NRF, and it is imperative to identify these factors for them to be addressed.

\section{Public procurement \\ Background on public procurement}

Public Affairs Research Institute (2014:13) points out that in the past, South Africa managed its procurement in a highly centralised manner. The procurement unit was full of employees who were general administrators without proper procurement education. The public procurement legislative framework at the time had a very low profile and had an element of exclusion for black people to benefit from the government procurement opportunities. The first period of reform in 1994 acted to an aspiration to include upcoming small and medium enterprises in government contracts. This had in the past largely gone to established non-black big companies. Ambe (2016:279) expressed that in 1995 transformation was at the heart of government to bring change and improve the lives of previously disadvantaged groups, that is, black and mixed race people to allow and prefer them to government tender opportunities to address past imbalances socio-economic activities. Davey and Gatenby (2017:215) mentioned that finally in the year 1996, the Constitution of South Africa was introduced. Wherein under section 217 (1) imposes the five foundational principles of public procurement on all organs of state in the national, provincial, and local sphere. These principles are fairness, equitability, value for money, transparency, and accountability.

Public Affairs Research Institute (2014:9) states that whilst the country introduced regulations and legislative framework 
to improve public procurement processes. Service providers particularly those groups who were previously disadvantaged thought that finally the government would give procurement opportunities to all. Whilst the public officials on the other side saw an opportunity to make South Africa a contracting state by appointing the private sector to come and do some of their job activities. They believed that service delivery in South Africa is increasingly performed by private companies. By appointing these external service providers, they opened a door for corruption as indicated by Munzhedzi (2016:6). He argues that public sector procurement and corruption are closely connected, 'they are inseparable twins' (Munzhedzi 2016:6). Saussier and Valbonesi (2018:1) indicate that procurement in the country is operating under financial constraints and restricted budgets at each level of government. Munzhedzi (2016:6) proposes that all of these can be avoided only if there is no political interference in government tender decisions, and if public institutions appoint qualified procurement practitioners who have knowledge, skills, and capacity to carry out procurement functions. The other significant element the author outlined was compliance with procurement regulations and ethical behaviour that could result in effective procurement processes.

\section{Theoretical perspectives of public procurement}

The agency theory: Mitnick (2019:3) states that the first scholars to initiate that a theory of agency is established were Stephen Ross and Barry Mitnick in the 1970s. Ross was responsible for the origin of the economic theory of agency and Mitnick for the institutional theory of agency. Ross put forward the study of agency in terms of problems of compensation and contracting. Mitnick set forth the now common insight that institutions form around agency and that they adapt to deal with the agency in response to the essential imperfection of agency relationships. Gelderman, Semeijn and Bouma (2015:72) believe that principal agency theory has the potential as a theoretical foundation to inspect the relationship between procurement officials and the executives in government departments. Yukins (2010:83) wrote that if applied correctly, the agency theory offers variable tools to identify and fix the ongoing challenges in procurement by introducing clear procurement policies and regulations. Chrisidu-Budnik and Przedanska (2017) are of the view that there are assumptions in the agency theory, firstly, that the efficiency of the principal's operations depends on the agent's acts and decisions. The decisions of both the principal and agent are made under conditions of mistrust and risk. This is because of both parties having contrasting objectives to some extent. Chrisidu-Budnik and Przedanska propose monitoring of procurement activities as a measure to reduce the mistrust between the principal and the agent.

Stakeholder management theory: Wittke (2014:2) states that R.E. Freeman was the first to apply the term 'stakeholder theory' to strategic management and to unpack the idea of stakeholder theory in his 1984 book titled Strategic management: A stakeholder approach with the view that organisations should bring value to all stakeholders. Okotie and Tafamel (2021:44) add that stakeholder theory embodies ethics, economics, law and policies, and political theory. Gelderman, Semeijn and Vluggen (2017:437) are of the view that stakeholder theory is a promising foundation for evaluating which actors influence the speed of implementation by meeting the needs of organisations to avoid poor service delivery. Marius (2017:56) argues that poor service delivery can be caused by ineffective procurement systems within the institution. The author further adds that the ineffectiveness of stakeholders in procurement activities could be caused by conflict or competition.

Transaction cost economic theory: Sumpikova et al. (2016:1750) mention that R. H. Coase was the first to describe the expression 'transaction costs' as an important part of an institution's decision-making. Ketokivi and Mahoney (2017:Online) indicate that transactional cost economic theory as a formal theory began in the late 1960s and early 1970 s as an attempt to understand organisational finances. Ketokivi and Mahoney (2017) further mention that this theory was also implemented to assist organisations with complex transactions to minimise waste in their spending. Sumpikova et al. (2016:1750) argue that generally, transaction costs have the potential to limit potential savings in government tenders. Amarasuriya (2018:15) mention that transaction cost economic theory can be used to explain that in every procurement process, cost will be incurred. This could be market research cost, contract cost, specification cost, and monitoring cost. This is the reason why procurement officials and service providers adhere to the organisation's policies and standards issued for the procurement process.

The above-mentioned theories (agency theory, stakeholder management theory, and transactional cost economic theory) are relevant to this study. What the NRF can adopt from the agency theory is the introduction of clear policies and guidelines as indicated by Yukins (2010:83) stating what is expected of the Project managers and Procurement officials in implementing the procurement plan, as this could reduce non-delivery of projects by the end of the financial year. Stakeholder theory is relevant to this study in the sense that the implementation of procurement plan requires stakeholder buy-in. There has to be a good working relationship between the Procurement officials and the Project managers. The NRF should look closely at the issue of conflict or competition amongst the stakeholders as mentioned by Marius (2017:56) and ensure that this does not affect the procurement plan implementation. In transactional cost economic theory, the NRF can learn to plan their procurements properly and to do thorough project needs to check if indeed they need that project. Some projects are included in the procurement plan but at the end of the financial year they are being cancelled and this shows wasteful expenditure because those projects have been budgeted for.

\section{Consequences of failing to undertake procurement planning}

Public procurement training Instrument for Pre-Accession Assistance Beneficiaries (2018:5) mentions that by not 
undertaking a procurement planning, the stakeholders, the finance unit, and the procurement team would work in isolation and be unaware of each other's needs. There would be no procurement plan linked to the strategic plan of the contracting authority. The requirements received by the procurement team would be surprises for which no preplanning would have been possible. Economies of scale would be lost because the requirements of different areas would be processed separately. Resource scheduling would be difficult and requirements would not be timed to the yearend of potential economic operators and so better deals could not be achieved.

To support the above ideas, the SCM review update conducted by National Treasury (2016a:4) mentions that the driver for procurement plans is the organisation's strategic plan and appropriation processes. Part of the legal requirement for all procuring entities to prepare strategic plans is the preparation and publishing of the entity's procurement plans that are properly costed and fed into the appropriation and budgeting processes. The review further indicates that improved demand management should result in improved planning of the entire supply chain cycle, alignment between budgets, strategy and projects, improved costing and reduction in the number of non-responsive or failed bids.

\section{Five general procurement principles for the effective implementation of the procurement plan}

Value for money: Zitha, Sebola and Mamabolo (2016:65) indicate that to procure goods and services, the officials involved in procurement need to ensure that value for money is received, service rendered needs to be of good quality. Neglecting this pillar results in the government procuring services at excessive prices whereas that money could have been used to enhance service delivery in other needy areas like local municipalities. Watermeyer (2014:2) mentions that value for money may be regarded as the optimal use of resources to attain the intended outcomes. Value for money is an explicit commitment to ensure that the best results possible are obtained from the money spent or maximum benefit is derived from the resources available.

Transparency and effective competition: As mentioned in a policy from Vaal University of Technology (2019:10) this requires a framework of procurement laws, policies, practices, and procedures that is transparent, that is, they must be readily accessible to all parties, and procurement process should be open to the public. From the National Treasury General Procurement Guidelines (2012:6), transparency implies that the public sector shall ensure procurement processes and award of contracts is done transparently. It encourages effective competition through procurement methods suited to market circumstances and observance of the provisions of the Preferential Procurement Policy Framework Act.

Ethics and fair dealings: Fairness means that all procurement processes are carried out fairly, in that all suppliers are dealt with even handily and where there is a conflict of interest it is recognised and dealt with amicably (Banda 2016:23). National Treasury General Procurement Guidelines (2012:6) highlight that every government official involved in the procurement of goods and services, more importantly, those who deal directly with suppliers must ensure that they do not compromise the work in the procurement process by accepting gifts. It further points out that should there be either government officials or service providers who intend to steal from the government using fraud or corruption such must be reported to assist in eliminating this unethical behaviour. Munzhedzi (2016:6) also added that the principle refers to the transparent, standardised, and easily available laws, policies, practices, and procedures. Organisations should promote openness of bids to suppliers all the time.

Accountability and reporting: Within the procurement structure all people exercising procurement functions must have regard to these guidelines and are accountable to management (National Treasury General Procurement Guidelines 2012:7). To add to the guidelines by the National Treasury, Sizani (2018:2) mentioned that to include this principle is to make sure that individuals and organisations are answerable for their plans, actions, and outcomes. Accountability refers to the obligation of public servants or an institution to account for their activities, provide information about decisions and actions, explain and justify their decisions. Through accountability, public servants are expected to be answerable for their actions, and most importantly that there should be consequences when duties and commitments are not met.

Equity: Means the application and observance of government policies that are designed to advance persons or categories of persons disadvantaged by unfair discrimination (Supply Chain Management for Public Service Learners Guide 2011:88). Van Rooyen (2019:Online) added by emphasising that the pillar was introduced to promote business with Previously Disadvantaged Individuals (PDIs). The author further adds that Small, Medium, and Micro Enterprises together with PDIs must play a bigger part in the development of the larger South African economy and also that any good procurement policy should address equity as a main element in the procurement process.

\section{Research methodology and design}

In this article, a qualitative research method was utilised whilst data were collected using unstructured interviews. According to Brynard, Brynard and Hanekom (2014:39), a qualitative method refers to research that produces descriptive data, generally the participants' own written or spoken words of their experience or perception. The study employed a case study research design. Heale and Twycross (2017:7) mention that a case study can be defined as an intensive, systematic investigation of a single unit or group in which the researcher examines in-depth data relating to several variables. This design was useful for this study because the main objective was to explore the factors hindering the implementation of the procurement plan in the NRF based on the official's 
experiences. The research philosophy that guided this study was the interpretivism paradigm because it enabled to get more insight into this problem and to also assist the researcher to make comprehensive and factual analyses.

\section{Data collection}

Kabir (2016:202) defines data collection as the process of gathering and measuring information on variables of interest, in an established systematic fashion that enables one to answer research questions, test hypotheses, and evaluate outcomes. Data were collected using unstructured interviews with 30 project managers, consisting of senior managers, middle managers, and intermediate staff. The unstructured interviews were conducted through face-to-face and telephonic interviews with all targeted participants being subjected to the same interview questions. Each interview took at least 30-35 min. The researcher also recorded the interviews with project managers after getting their consent. The recordings were used to compare the notes taken during the interview and ensured that correct information was captured. The purpose of the interviews was to allow project managers involved in the procurement of goods and services above R500 000.00 to give in-depth answers regarding the factors that hinders the implementation of some of their project listed in the procurement plan. The interviews took longer than anticipated. This was because of some project managers rescheduling the appointment as they were working on key national projects that required extra working hours, whilst others did not want to participate and ended up cancelling the appointment. In addition to the primary data collection, the researcher also made use of a literature review related to the study.

\section{Study population and sampling strategy}

The target population for this study included project managers who were involved in the procurement of goods and services above R500 000.00. These project managers were Senior managers, Middle managers, and Intermediate staff from the NRF. Procurement plan is managed from supply chain unit; however, the custodians of the procurement plan are the project managers. Project manager can be anyone who has a need and want to procure goods and services above R500 000.00 from the external service providers. As per the National Treasury SCM Instruction 2 of 2016 and 2017, the project managers have a responsibility to ensure that their projects are implemented on time, at the right quality and at the right quantity at the end of the financial year. This is the reason why the study targeted only the project managers in order to achieve the objective of this study which was to find out what are those factors hindering the implementation of the procurement plan at the NRF.

To get the relevant data, a non-probability purposive sampling technique was used to select the participants. Alvi (2016:11) mentions that non-probability sampling is used when the population does not have an equal chance to participate in the investigation. The study used purposive sampling technique which relied on the subjective judgement of the researcher. The National Treasury SCM Instruction 2 of 2016 and 2017 requires institutions to have and implement procurement plan for all projects above R500 000.00 VAT Incl. In this study, only project managers who have implemented projects listed in the procurement plan above R500 000.00 in the NRF before were the participants. The researcher only managed to interview 30 out of the 35 targeted participants because some project managers cancelled their appointments whilst others did not respond to the interview invitations or were not interested.

\section{Data analysis}

The data collected were analysed using content and thematic analysis. Moretti et al. (2011:1) describe content analysis as a method to classify written or oral materials into identified categories of similar meanings. Alhojailan (2012:40) mentions that thematic analysis is used to analyse and present themes (patterns) that relate to the data. It allows the researcher to determine the relationship between concepts and compare them with the duplicated data. After collecting the data, the data were examined to identify themes, and then codes were created under each theme. Where similar data occurred, the researcher used interpretation to combine several codes into a single theme.

\section{Validity and reliability}

In qualitative research, validity is concerned with the trustworthiness of the data. Babbie et al. (2012:276) mention that trustworthiness refers to the accuracy of the research findings to convince the audience on the validity and reliability. It comprises four criteria which are credibility, consistency, transferability, and confirmability. Credibility was ensured by noting the answers given by the project managers in an interview template sheet for each participant using exact quotes from the participants to authenticate the research findings. No language barrier occurred as the terms used in the interview questions were phrased in simple language. The participants were allowed to voice their opinions freely and seek clarity before responding to questions. Consistency was maintained throughout the interviews which provided trustworthiness of the findings. To establish the confirmability of the data, the interviews were recorded using a voice recorder where permission was granted with the purpose to compare the results later and ensure that correct information is captured. The researcher was personally asking questions and taking notes during the interviews to ensure accuracy in the information capturing process.

\section{Demographic details of participants}

Table 1 shows 30 participants who were interviewed. The rationale in collecting demographic information was to determine their level of education and also the position that the participants hold. The participants consisted of eight senior managers, 12 middle managers, and 10 officials in the 
TABLE 1: Demographic information

\begin{tabular}{lccccc}
\hline Description & Capacity & Degree & Honours & Masters & $\begin{array}{c}\text { Doctor of } \\
\text { Philosophy }\end{array}$ \\
\hline Senior managers & 8 & 0 & 0 & 5 & 3 \\
Middle managers & 12 & 0 & 4 & 8 & 0 \\
Intermediate staff & 10 & 6 & 1 & 3 & 0 \\
\hline Total & $\mathbf{3 0}$ & $\mathbf{6}$ & $\mathbf{5}$ & $\mathbf{1 6}$ & $\mathbf{3}$ \\
\hline
\end{tabular}

intermediate positions and also included their level of qualification. All the participants have been involved in the implementation of the procurement plan.

\section{Presentation of the findings}

This section presents the key findings of this article. The research's objective was to examine those factors that hinder the progress of the NRF's procurement plan. The data were analysed and presented based on the participants' opinions and views under the following theme:

\section{Factors hindering the implementation of the procurement plan in the National Research Foundation}

The research question that the study sought to answer was, what are those factors that hinders the implementation of the procurement plan in the NRF. From the interviews, the factors that hinder the implementation of the procurement plan were identified and are discussed in the following subsection.

\section{Ignorance from Bid Evaluation Committee members}

The findings revealed the ignorance by bid evaluation members (BEC) who do not make comments when evaluating bid documents. This makes it difficult when the final decision has to be made because they just agree with everything other BEC members suggest. Respondent 21 who was the intermediate staff mentioned below that:

'Review of documentation by BEC members, some need to be followed a number of times before they can check the documents provided to them. Others do not even comment on the documentation; they just agree with everything.'

This should be stopped as these are the most crucial role players in a tender process. They are the ones who select and recommend to the Bid Adjudication Committee the potential service provider who will execute the project. If some of the BEC members are ignorant then this means that at times unqualified service providers could be recommended. This can lead to incorrect deliverables that fall short of the bid requirements resulting in wasteful expenditure.

\section{Knowledge barrier between Scientists and SCM Practitioners}

The respondents identified that there was a knowledge barrier between Scientists and SCP Practitioners. They argued that some Scientists have little knowledge in finance and SCM. Respondent 25 - senior manager said:
'I'm a scientist with little education in finance and procurement, so sometimes there are challenges in talking the same language as experts in SCM.'

Knowledge about SCM processes should not be a factor to hinder the project's success. Both Scientists and SCM officials should create a time for training on SCM regulations and instructions. It could be argued that this sounds like an excuse.

\section{Lack of dedication from SCM Officials}

The results also reveal that some respondents were highly unsatisfied with the level of service they receive from the SCM Office. They note there is a lack of dedication from Supply Chain officials. They stated that SCM officials need to be willing to assist project managers through the procurement process. Respondent 15 who is the senior manager had this to say:

'There is a lack of dedicated procurement staff that needs to be placed within the business unit to assist project leaders and endusers through the procurement process.'

The SCM officials should do their job and assist the project managers with projects as they may not be an expert in SCM processes. Lack of dedication can be caused by several circumstances; it could be that someone is just not interested in doing their work or can be about contractual issues with their manager or employer. If the lack of dedication is because of contractual issues, the manager or the employer must intervene as the employee's concerns must be heard and be addressed.

\section{Lack of support and communication from supply chain managers}

It was discovered that some SCM Managers only communicated via email. There is no communication to remind them of the procurement plan. It is only when the procurement plan is due when they receive an email requesting the project update and they often forget about the plan. Respondent 10 who was the middle manager expressed himself as follows:

'No communication from SCM to project managers reminding them of the procurement plan, only when is due that is when you receive an email as a reminder.'

This is unacceptable at all and not even expected from SCM managers. Furthermore, it is surprising because SCM managers in most cases are the drivers of SCM regulations and policies in government institutions. It could be argued that some SCM managers would just watch government money being misused because how can you manage the procurement plan which contains millions and billions of rands on an email without physical communication and support to the project managers? Is it because it comes from the government's pocket and not from the individual? The money spent on public entities projects is tax payer's money and SCM Managers and government institutions must manage it accordingly. 


\section{No procurement plan training provided}

The research findings indicated that the SCM Managers do not train or have a workshop prior to the preparation of the procurement plan to clearly state the SCM requirement with regard to the procurement plan. Others believe that the procurement plan needs to have a buy-in from the project management team. Some respondents highlighted that unfamiliarity with the financial and legal terms involved in the process. This results in procurements often being cancelled because of a lack of understanding from those drafting the advertisements. Respondent 8 an intermediate staff states that:

'There is a need for a workshop by SCM Managers. To announce the procurement plan people must be shown the process flow and they can ask a question directly and not on emails and also this can enhance sharing of information as project managers can learn from each other on how they prepare, implement and monitor their projects.'

Respondent 17 , who is a middle manager also stated the following:

'There is some staff who don't even know what procurement is in the organisation, they start in the middle of the project implementation i.e. they are just invited to sit in a BSC meeting by their business heads. SCM does not educate the staff about the procurement, only senior management seems to know about it.'

Project managers must be trained on how to conduct market research before putting a project on the procurement plan and also on how to write a clear bid specification.

\section{Time management}

Some of the respondents felt that their time is compromised as their core function is often neglected whilst busy preparing specification that has SCM terms. They argue that SCM falls out of their functional tasks and this often results in them showing poor performance in their tasks. In support of this factor, Respondent 2, the middle manager motivated his answer by saying:

'Bid documents are often first drafted by the end-users or technicians and project managers who are not schooled in finance, procurement, or legal document drafting. Also, these individuals fulfil other core functions for the organisation and have to dedicate a large amount of additional time to procurement, which falls out of their range of core functional tasks. This often results in compromised time-management and unsatisfactory performance in their core functions.'

Why would other project managers feel that procurement is not part of their functional task when they need money from the government to execute their projects? It is time that project managers take into consideration procurement functions in government institutions. Project managers should know that although they are scientists or engineers involved in conducting research in astronomy they will need instruments or equipments to achieve their goals. And to get those resources they will need financial resources which are provided by the government. Therefore, the procurement role must form part of their functional tasks.

\section{Delay from Procurement Board Committee}

The procurement board also delays the process and they sometimes question the amount of money you want to spend on a specific project. By the time they get back to you, you find out that the time planned for the procurement plan has passed. Respondent 19 the middle manager said:

'Procurement board committee delays the process as they sometimes question the amount of money you want to spend on a certain bid.'

This type of task by the procurement board committee should be carried out at the preparation stage of the procurement plan and not when the project is in the implementation process. This can cause delays in the project.

\section{Non-responsive suppliers}

The results also identified that sometimes suppliers do not respond to the tender advert. Respondent 26 the middle manager has this to say:

'Bidders not submitting mandatory documentation with proposals, for one of my projects all bidders were disqualified for not submitting the documentation, this then leads to the tender process having to start all over again and most cases delay the project by 3 to 4 months.'

Service providers must complete tender documentation to avoid opportunists inserting information that may put them at the risk of fraud cases. Some service providers who commit fraud can be caught but that usually wastes government resources. Therefore, to avoid such incidents, they should complete the tender documentation from the beginning so that if there is some dodgy information, it can be eliminated at the beginning.

\section{Resignation of project leaders}

Another factor highlighted by the respondents was the issue of a project leader resigning before the project can commence. This could also delay the process. Respondent 18 the middle manager said:

'Project leaders leave during the progress of the projects causes a delay in the execution.'

To address this, they must be skills transfer from the project leader to the other project team members in case the project leader resigns otherwise the projects will be delayed because someone has resigned.

\section{Budget restriction}

Budget restriction hinders the implementation of the procurement plan in the NRF by affecting the acquisition of the right goods or services. Respondent 15 middle manager only said:

'Budget restrictions on acquiring the right goods/services. This is offset by performing a market survey.'

Budget restrictions are introduced to cut unnecessary costs and improve the management of resources. It can be argued 
that some project managers would prefer favour service providers who are well established but expensive. However, this should not be a factor because if a service provider does not deliver as promised they can be reported to the national treasury and might end be restricted from doing business with government institutions for a period of time.

\section{Opportunistic suppliers}

to Awarding the bid or tender to inappropriate suppliers who quote less just to get a project and later request variation of order. This could also lead to projects not being completed on time, and also involves the issues of low quality services being delivered. Respondent 14 the middle manager said:

'Service providers often price for minimal staff for the project just to be awarded a project, this often leads to a project not being able to be completed on time or quality issues to rush to get the job done.'

This finding shows a serious violation of government procurement regulations. It is certainly a fraud. The service providers who steal from the government like this are not only delaying the procurement plan progress but also pull government finances down because this is a waste if a low quality is delivered.

\section{Unavailability of key approvers/delegated authority}

Unavailability of delegated authority who approves the bid document for advertisement, BEC minutes, and Bid Adjudication Committee recommendations to the Chief Executive Officers. Respondent 2 a senior manager has this to say:

'Document not being approved timeously due to processes between review committees or unavailability of approvers or key players.'

Now, this should not be a factor why not delegate. This is the reason why the institution must not rely on one person to approve tender documentation but at least two in case one is not available.

\section{Lack of awareness}

Some of the project managers pointed out that they are not aware of the importance of the procurement plan in the organisation. Respondent 29 the intermediate staff mentioned:

'Yes, the plan is circulated to us to put in projects that are above R500000.00 but honestly I am not aware of its importance. I don't think SCM highlight the importance of the procurement plan enough.'

Supply chain unit must do better, circulating the procurement plan and not stating the importance of why the project manager has to put in those information on the procurement plan is unacceptable. The SCM unit should host workshops with the project managers and emphasise the reasons why the procurement plan has to be completed and also highlight its impact.

\section{Lack of SCM capacity}

There was a project manager who stated that there is a lack of SCM technical specialists to assist in conducting need analyses. The project manager also mentioned that the person should be assigned a role to oversee the procurement plan. The person mentioned below:

'There is a lack of SCM technical specialists to assist us to do need analysis such as market research. That person also need to oversee the NRF procurement plan, do follow ups and ensure the procurement plan is effectively implemented. Here, I have seen the very same person who facilitates procurement plan sitting in the tender bid committee meetings and also doing other SCM related work.' (Respondent 30 intermediate staff)

The NRF should look at capacity building to ensure that they have enough SCM specialists who deals with or are assigned to assist project managers in the implementation of projects that forms part of the procurement plan.

\section{Discussion}

The results above showed that there is still a lot to be done in the NRF when it comes to the implementation of the procurement plan. The findings revealed that the problem has always been there and unless the needed attention is given, these factors will occur during every financial year. Some project managers mentioned that SCM officials lack dedication to their work. Kiage (2013:63) highlights the need for dedicated stakeholders in implementing effective and efficient procurement plans. Proper implementation can only be achieved by staff members who are dedicated; otherwise, their flaws will appear in the process. It was revealed that BEC members are ignorant and do not provide comprehensive contributions when evaluating the bids received. Basu (2011:6) confirmed that some project managers still do not recognise the importance of supply chain function in the organisation. The results revealed that there is a knowledge barrier between Scientists and SCM Practitioners. Earnest and Dickie (2013:11), who conducted a study on procurement, projects, and planning, found that lack of training results in poor procurement planning, and therefore project managers will often take longer to complete the bid specification as they are not trained on how to complete it.

The research findings also revealed that SCM Managers only communicate with them via email. This result concurs with the assertions by Brahim, Abada and Muhindo (2014:228) who conducted a study on the implementation of procurement plan and found out that there is no good cooperation between procurement and user department in the preparation and implementation of the procurement plan. Furthermore, the findings concurred with the finding by Kiarie and Ogubala (2014:15) who found that there is also a lack of full support from the top management and often project managers feel neglected. The results disclosed that the SCM Managers do not train or conduct a workshop with project managers to clearly state the SCM requirement regarding the procurement plan. There was also one who mentioned lack of awareness regarding the importance of 
the procurement plan. These findings agree with the finding from Lema (2013:55) who assessed factors affecting the implementation of annual procurement plan and found out that there is a lack of awareness and skills to decisionmakers concerning the use of appropriate procedures and policies in the implementation of the annual procurement plan.

The results also showed that sometimes suppliers do not respond to bids. This finding concurs with the one from Doloi et al. (2012:485) who in their study found out that lack of skilled project managers for specialised equipment is a big factor as it causes a situation where proper equipment planning is not done. This article adds that if suppliers do not respond to the bid invitation it may be because of misspecification in the tender advert. In addition, the study findings showed that budget restriction hinders the implementation of the procurement plan by affecting the acquiring of the right goods or services. This finding corresponds with those of Lema (2013:55) who found that insufficient budget to cover the project needs is a problem.

\section{Conclusion and managerial implications}

In conclusion, the study found that some SCM officials lack dedication to their work when assisting project managers with a procurement plan. It is therefore recommended that the NRF business heads should offer support by regularly reviewing the workloads of SCM officials to assist them to fulfil their responsibilities. Some respondents mentioned that they are scientists and does not understand SCM language, which means that there is a knowledge barrier. It is recommended that SCM officials train Scientists on SCM regulations and policies so that this is not an excuse for going forward. Evidence collected has pointed out that SCM managers manage procurement plans via emails. There is lack of awareness regarding the importance of procurement plan and no support is provided to project managers. This is wrong as there must be an intervention from the business unit's heads. Based on this finding, the study concludes that SCM managers violate national treasury's effort to ensure that public fund is managed effectively through procurement plans. It is, therefore, recommended that they are held accountable and must do their job.

The study further found that project managers felt that their time is compromised by doing procurement functions which is not part of their functional task. It is recommended that business units' heads put procurement plan as a key criterion on the project manager's performance agreements. Based on this finding, the study further concludes that whether one is an SCM official or not if their project needs funds then procurement function is part of their functional tasks and time must be allocated for that task. The study also found that there is a lack of SCM technical specialists to assist project managers on the implementation of projects that form part of the procurement plan. The NRF is recommended to look into capacity building and ensure that there is enough SCM specialists to assist project managers to implement their projects effectively. Overall the study concludes that SCM officials should emphasise to the project managers, the importance of national treasury procurement regulations and instructions related to procurement plan in order to manage public funds effectively. The findings of this study can assist officials involved in procurement at different government institutions to be aware of these factors and improve their internal SCM policies in managing procurement plans. The procurement plan contains much money wherein the bulk of it comes from the government. It should not be taken as a monitoring tool of projects but rather as an operational report to effectively manage public funds.

\section{Acknowledgements Competing interests}

The authors declare that no competing interest exists.

\section{Authors' contributions}

R.M.M and T.K. made a significant contribution to this project as they co-wrote the manuscript.

\section{Ethical considerations}

The study followed the ethical clearance in communicating with the participants, in line with the ethical measures stated by the Tshwane University of Technology, Faculty Committee for Research Ethics. This includes confidentiality, voluntary participation, and anonymity of the participants.

\section{Funding information}

This research received no funding from any funding agency in the public, commercial or not-for-profit sectors.

\section{Data availability}

Data sharing is not applicable to this research as no new data were created or analysed in this article.

\section{Disclaimer}

The views and opinions expressed in this journal article are those of the authors and do not necessarily reflect the official policy of the agency mentioned in the article.

\section{References}

Alhojailan, M.I., 2012, 'Thematic analysis: A critical review of its process and evaluation', West East Journal of Social Sciences 1(1), 40

Alvi, M., 2016, A manual for selecting sampling techniques in research, University of Karachi, Paper No.70218, 11-33, viewed 20 May 2020, from https://mpra.ub.unimuenchen.de/70218/.

Amarasuriya, D.G.K.S., 2018, 'A Systematic review of literature on theories available on procurement compliance', International Journal of Engineering Research and Management (IJERM) 5(9), 15

Ambe, I.M., 2016, 'Public procurement trends and development in South Africa' Journal of Business and Management 3(3), 279-281. https://doi.org/10.17261/ Pressacademia.2016.351

Babbie, E., Mouton, J., Voster, P. \& Prozesky, B., 2012, The practice of social research, Oxford University Press, Cape Town.

Banda, U., 2016, Supply chain management policy, City of Tshwane, Pretoria. 
Barasa, H.W., 2014, 'Procurement practices affecting effective public projects implementation in Kenya: A case study of Kenya Civil Aviation Authority', European Journal of Business and Management $6(6), 52$.

Basu, R., 2011, Managing project supply chains, Gower Publishing Limited, Aldershot.

Bolton, P., 2016, 'Public Procurement as a tool to Drive Innovation in South Africa', Pioneer in Peer-Reviewed, Open Access Online Law 19, 4-26. https://doi. org/10.17159/1727-3781/2016/v19i0a1286

Brahim, F.J., Abada, O. \& Muhindo, A., 2014, 'Implementation of procurement planning in parastatal organisations: A case study of Tanzania Postal Bank Head Quarters in Dar-es-salaam', International Journal of Academic Research in Management 3(3), 228.

Brynard, D.J., Brynard, P.A. \& Hanekom, S.X., 2014, Introduction to research, 3rd edn., Van Schaick, Pretoria.

Chrisidu-Budnik, A. \& Przedanska, J., 2017, 'The Agency theory approach to the public procurement system', Wroclaw Review of Law, Administration \& Economics 7(1) procurement system', Wroclaw Review of Law, Adm
154-156. https://doi.org/10.1515/wrlae-2015-0059

Davey, J. \& Gatenby, A., 2017, The government procurement review, 5th edn., Law Business Research Ltd, London.

Doloi, H., Sawhney, A., Iyer, K.C. \& Rentala, S., 2012, 'Analysing factors affecting delays in Indian construction projects', International Journal of Project Management 30(4), 485. https://doi.org/10.1016/j.ijproman.2011.10.004

Earnest, J. \& Dickie, C., 2013, 'Procurement, projects and planning: Assessing Kosovo's Post War Governance', Technology, Innovation and Supply Chain Management Competitive Session 15, 11-12.

Gelderman, C.J., Semeijn, J. \& Bouma, F., 2015, 'Implementing sustainability in public procurement: The limited role of procurement managers and party-political executives', Journal of Public Procurement 15(1), 72. https://doi.org/10.1108/ executives', Journal of
JOPP-15-01-2015-B003

Gelderman, C.J., Semeijn, J. \& Vluggen, R., 2017, 'Development of sustainability in public sector procurement', Public Money \& Management 37(6), 437. https://doi. org/10.1080/09540962.2017.1344027

Heale, R. \& Twycross, A., 2017, 'What is case study', Evidence Based Nursing 28(1), 7. https://doi.org/10.1136/eb-2016-102514

Kabir, S.M.S., 2016, Methods of data collection, Curtin University, viewed 08 June 2020, from http://dsc.du.ac.in/wp-content/uploads/2020/04/Field-TechniquesMerits-Demerits.pdf.

Ketokivi, M. \& Mahoney, J.T., 2017, Transaction cost economics as a theory of the firm, management, and governance, October 26, viewed 10 December 2020, from https://oxfordre.com/business/vi
acrefore-9780190224851-e-6.

Kiage, J.O., 2013, 'Factors affecting procurement performance: A case of Ministry of Energy', International Journal of Business and Commerce 3(1), 8.

Kiarie, M.D. \& Ogubala, R.A., 2014, 'Factors affecting procurement planning in country Government Kenya: A case study of Nairobi City Country', International Journal of Economics Commerce and Management 2(11), 15.

Komakech, R.A, 2016, 'Public procurement in developing countries: Objectives, principles and required professional skills', Public Policy and Administration Research 6(8), 20.

Lema, A.M., 2013, 'Assessment of factors affecting implementation of annual procurement prasha, Tanzania', BA dissertation, The Open University of Tanzania.

Marius, G.O., 2017, 'Stakeholder involvement and nature of procurement process in the United Nations Organization Stabilization Mission in the Democratic Republic of Congo (MONUSCO) Entebbe Support Base', International Journal of Supply Chain and Logistics 1(2), 56-62. https://doi.org/10.47941/ijscl.149

Mitnick, B.M., 2019, Origin of the theory of agency: An account by one of the theory's originators, viewed 09 December 2020, from https://ssrn.com/abstract=1020378.

Moeti, K. (ed.), 2014, Public finance fundamentals, 2nd edn., Juta, Cape Town.

Moretti, F., Van Vliet, L., Bensing, J., Deledda, G., Mazzi, M., Rimondini, M. et al., 2011, 'A standardized approach to qualitative content analysis of focus group discussions from different countries', Patient Education and Counselling 2(3), 420-428. https://doi.org/10.1016/j.pec.2011.01.005

Mukonza, R.M., 2015, Chombo shoots down Marondera budget: The irony! April 02 viewed 29 May 2020, from https://nehandaradio.com/2015/04/02/chomboshoots-down-marondera-budget-the-irony/
Munzhedzi, P.H., 2016, 'South African public sector procurement and corruption: Inseparable twins?', Journal of Transport and Supply Chain Management 10(1), 6 Art.\#197, 1-8. https://doi.org/10.4102/jtscm.v10i1.197

National Research Foundation, 2020, Approved Procurement plan reporting 2019/2020, National Research Foundation (NRF), Pretoria.

National Research Foundation, n.d., Short history of the National Research Foundation, viewed 30 April 2020, from https://www.nrf.ac.za/about-nrf/history.

National Treasury, 2011a, Guidelines on the implementation of Demand Management, National Treasury, Pretoria.

National Treasury, 2011b, National Treasury Instruction note No 33. Implementation of the framework for strategic plans and annual performance plans, National Treasury, Pretoria.

National Treasury, 2012, National Treasury General Procurement Guidelines, National Treasury, Pretoria.

National Treasury, 2016a, SCM review update, National Treasury, Pretoria.

National Treasury, 2016b, SCM instruction 2 of 2016/17 procurement plans Submission and reporting, National Treasury, Pretoria.

Okotie, W. \& Tafamel, E.A., 2021, 'Transparency and public procurement practices in the Nigerian Civil Service', African Journal of Business Management 15(1), 44. https://doi.org/10.5897/AJBM2020.9087

Public Affairs Research Institute (PARI), 2014, The contract state: Outsourcing \& decentralisation in contemporary South Africa, Johannesburg, viewed 29 June 2020, from http://www.summerschool.uct.ac.za/sites/default/files/image tool/images/4/2018SummerSchool/The-Contract-State-01082014.pdf

Public Procurement Training Instrument for Pre-Accession Assistance Beneficiaries, Module C, 2018, viewed 10 December 2020, from http://www.sigmaweb.org/ publications/46179115.pdf

Saussier, S. \& Valbonesi, P., 2018, 'Introduction to the special issue: Public Procurement-new theoretical and empirical developments', Economia e Politica Industriale 45, 1. https://doi.org/10.1007/s40812-018-0091-3

Schoonenboom, J. \& Johnson, R.B., 2017, 'How to conduct a mixed methods research design', KZfSS Kölner Zeitschrift für Soziologie und Sozialpsychologie 69(2), 107. https://doi.org/10.1007/s11577-017-0454-1

Sizani, R., 2018, Improving accountability and transparency in the public sector by examining how to depoliticise executive governance, including professionalization of the public sector, state owned enterprises and public procurement, Public Service Commission to Public Affairs Research Institute, Johannesburg.

Sumpikova, M., Busina, F., Grega, M., Nemec, J. \& Orviska, M., 2016, 'Transaction costs in the public procurement: Selected findings in Czech and Slovak conditions', The 10th International Days of Statistics and Economics, 08-10 September 2016, Prague, p. 1750.

Tshwane University of Technology, 2011, Supply chain management for public service learner guide, Palama, Pretoria.

Watermeyer, R., 2014, 'Realising value for money through procurement strategy in the delivery of public infrastructure', 8th CIDB Post Graduate Conference, February 2014, University of the Witwatersrand, Johannesburg, p. 2.

Wittke, K., 2014, 'The contribution of stakeholder theory to supply chain management: A theory evaluation', 3rd IBA Bachelor Thesis Conference by University of Twente, Faculty of Management and Governance, Enschede, 03 July 2014, p. 2.

Vaal University of Technology, 2014, Procurement policy and procedures, viewed 29 June 2020, from https://www.vut.ac.za/wp-content/uploads/2019/07/POLICY. pdf.

Van Rooyen, W., 2019, The 5 pillars of procurement and supply chain management Milnerton, viewed 29 June 2020, from https://www.sa-tenders.co.za/content/ hints-tips-and-news/5-pillars-procurement-and-supply-chain-management.

Yukins, C.R., 2010, 'A versatile prism: Assessing procurement law through the principal-agent model', Public Contract Law Journal 40(1), 83.

Zitha, H.E., Sebola, M.P. \& Mamabolo, M.A., 2016, 'Compliance to procurement processes, deviant behaviour and effects on service delivery in the public sector', Journal of Public Administration and Development Alternatives 1(1), 65-67. 


\section{Appendix 1}

TABLE 1-A1: Terms and abbreviations used in the study Conceptual definitions.

\begin{tabular}{ll}
\hline Terms & Abbreviations \\
\hline BEC & Bid Evaluation Committee \\
NRF & National Research Foundation \\
SCM & Supply Chain Management \\
\hline
\end{tabular}

Public Procurement - Bolton (2016:4) defines public procurement as a purchase of goods and services by government or public entities to fulfil their various functions to achieve a specific goal. Komakech (2016:20), public procurement is one of the many functions of the government that presents good potential for helping public institutions to achieve their goals.

Procurement plan - Kiage (2013:61) states it is a plan that outlines and documents all of the purchases from outside service providers that will be needed to support the needs of a specific institution. Barasa (2014:52) mentions that a procurement plan is important as it entails defining the activities, scheduling, and listing and indicating project managers who are required to implement the project. The plan also shows how much money will be spent in a time-framed manner and lastly, it enhances project monitoring and control. 